\title{
NUSAP1 wt Allele
}

National Cancer Institute

\section{Source}

National Cancer Institute. NUSAP1 wt Allele. NCI Thesaurus. Code C126504.

Human NUSAP1 wild-type allele is located in the vicinity of 15q15.1 and is approximately $48 \mathrm{~kb}$ in length. This allele, which encodes nucleolar and spindle-associated protein 1, plays a role in cell division. 